\title{
INVESTASI VALUTA ASING DAN PENERAPANNYA MENGGUNAKAN SOFTWARE METATRADER: SEBUAH ALTERNATIF
}

\author{
Yoyo Cahyadi \\ Accounting and Finance Department, Faculty of Economics and Communication, BINUS University \\ Jln. K. H. Syahdan No. 9, Palmerah, Jakarta Barat 11480 \\ yoyo.cahyadi@gmail.com
}

\begin{abstract}
Investment in foreign exchange is growing very fast recently because of liberal market system and technology advancement. Technology makes investment in foreign exchange can be performed easier, faster, and simple regarding the foreign exchange market open 24 hours in working days. In fact, there are just a few people who understand foreign exchange investment and how to use the tool needed in this kind of investment. The purpose of this paper is to give a description on how to use foreign exchange as an investment and using MetaTrader 5 software as a tool of it. Its features support foreign exchange market which often moves very fast. Understanding of foreign exchange market and software operation are the first step to start the investment.
\end{abstract}

Keywords: Foreign exchange, investment

\begin{abstract}
ABSTRAK
Investasi valuta asing saat ini sedang banyak berkembang karena didukung oleh sistem pasar bebas dan kemajuan teknologi. Dengan bantuan teknologi, investasi valuta asing dapat dilakukan secara lebih mudah, cepat dan praktis mengingat pasar valuta asing buka selama 24 jam pada hari kerja. Namun pada kenyataannya, masih sedikit orang yang mengetahui mengenai berinvestasi dalam valuta asing serta bagaimana menggunakan alat bantu yang diperlukan dalam investasi tersebut. Tulisan ini bertujuan untuk memberikan gambaran bagaimana valuta asing dapat diterapkan sebagai salah satu bentuk investasi serta penggunaan software MetaTrader 5 sebagai alat bantunya. Fitur-fitur dalam MetaTrader 5 mendukung situasi pasar valuta asing yang seringkali bergerak sangat cepat. Pengenalan akan pasar valuta asing dan cara penggunaan software menjadi langkah awal yang harus dilakukan untuk memulai investasi.
\end{abstract}

Kata kunci: Valuta asing, investasi 


\section{PENDAHULUAN}

Di era kemajuan dunia finansial sekarang ini, banyak tawaran investasi yang disodorkan dengan berbagai janji keuntungan, kemudahan, dan kecepatan transaksi yang sering kali sangat menggiurkan. Berbagai tawaran tersebut menghasilkan banyak alternatif investasi yang dapat menjadi pilihan. Sebut saja saham, emas, dirham, index, valuta asing, dan masih banyak lagi.

Widoatmodjo et all (2012:4) membagi pilihan investasi secara umum ke dalam dua golongan besar yaitu real asset investment dan financial asset investment. Real asset investment adalah komitmen mengikatkan aset pada sektor riil, seperti perdagangan, industri, pertanian, dan lain-lain di luar sektor keuangan. Sedangkan financial asset investment atau sering juga disebut portfolio investment adalah komitmen untuk mengikatkan aset pada surat-surat berharga (securities), yang diterbitkan. Adanya perantara merupakan salah satu ciri investasi di sektor keuangan.

Namun, investasi di sektor keuangan tentunya tidak sebatas pada surat berharga. Dengan kemajuan pemikiran di dunia keuangan, banyak alternatif investasi di sektor keuangan di luar kategori surat berharga, seperti misalnya valuta asing dan produk turunannya (derivative). Dan dengan dukungan teknologi dewasa ini, investasi tersebut menjadi tidak berwujud (paperless). Begitu juga investasi pada valuta asing yang sudah menggunakan sistem online tidak lagi menggunakan bukti fisik. Semua transaksi dan buktinya diproses dan disimpan di dalam sistem. Hal tersebut membuat transaksi valuta asing menjadi lebih mudah, sederhana, ringkas dan cepat.

Valuta asing hanya merupakan salah satu alternatif yang dapat dipakai sebagai instrumen investasi di sektor keuangan. Penggunaan valuta asing sebagai alat investasi tidak lepas dari dukungan sistem pasar bebas dan kemajuan teknologi. Tanpa dukungan teknologi yang memadai, investasi valuta asing masih dapat dilakukan, namun dengan fleksibilitas yang terbatas, misalnya dengan cara membeli dan menjual mata uang asing secara fisik.

Sebagai instrumen investasi, valuta asing akan memberikan keuntungan jika nilai tukar atau kurs valuta asing yang menjadi target investasi tidak menganut kebijakan yang mematok kurs pada nilai tertentu. Dengan demikian valuta asing yang dipilih haruslah mata uang yang memiliki keleluasaan untuk bergerak di pasar bebas atau menganut kebijakan nilai kurs mengambang (floating rate) dan tidak banyak diintervensi oleh pemerintahnya. Biasanya mata uang dari negara maju seperti US Dollar (USD), Euro (EUR) dan British Pound sterling (GBP) dapat menjadi alternatif pilihan karena mata uang tersebut dibiarkan bergerak bebas mengikuti mekanisme pasar atau penawaran dan permintaan di pasar.

Pojarliev dan Levich (2008:19-20) menyebutkan bahwa terdapat empat macam hal yang biasanya menjadi strategi untuk memperoleh keuntungan dari pasar valuta asing yaitu carry factor (meminjam mata uang berbunga rendah untuk berinvestasi di mata uang berbunga tinggi), trendfollowing factor (memerhatikan sinyal-sinyal tren dan perubahannya), value factor (mata uang mana yang under- atau overvalue terhadap mata uang lainnya), volatility factor (menggabungkan dengan produk valuta asing lain yang harganya sensitif terhadap volatility (pergerakan) suatu mata uang seperti foreign exchange option). Keempat hal tersebut pada gilirannya juga merupakan faktor penggerak dari sebuah pasangan mata uang. Peluang dari berbagai strategi tersebut membuat pasar valuta asing bergerak dinamis.

Sesuai dengan pendapat Jones (2010:2) bahwa "investasi adalah komitmen atas dana terhadap satu aset atau lebih yang akan dipegang selama jangka waktu tertentu”, maka untuk valuta asing ini perlakuan yang diterapkan kurang lebih juga mengamini pendapat tersebut walaupun terdapat modifikasi. Modifikasi terjadi karena valuta asing yang menjadi target investasi tidak selalu harus 
dipegang selama jangka waktu tertentu, namun dapat dilakukan teknik jual-beli secara terus-menerus atau yang sering disebut trading.

Ardian (2012:1) menyatakan bahwa "trading dapat diartikan sebagai usaha atau kegiatan beli (buy) atau jual (sell) secara terus-menerus, regular dengan jumlah yang relatif kecil dan konsisten untuk mendapatkan keuntungan”. Dari definisi tersebut kata kunci yang perlu diperhatikan adalah "terus-menerus" dan "konsisten”. Hal tersebut menunjukkan bahwa kegiatan trading adalah kegiatan berulang dan berjangka waktu panjang.

Kegiatan trading dapat dianalogikan seperti lari marathon, bukan seperti lomba lari sprint yang berjarak pendek yang pesertanya harus mengerahkan seluruh tenaga sekaligus dalam waktu singkat karena jarak tempuh yang pendek. Ibarat lari marathon, orang yang melakukan kegiatan trading harus membagi seluruh sumber daya yang dimilikinya agar tidak habis dalam waktu singkat. Sumber daya di sini dapat berarti dana, konsentrasi, tenaga, dan lain-lain. Walaupun kegiatan trading dapat dilakukan selama 24 jam sehari selama hari kerja, penerapannya di lapangan tidaklah mungkin dilakukan, kecuali jika menggunakan robot atau sistem otomatis tertentu. Demikian juga dengan dana, strategi cut loss atau stop loss harus diaplikasikan dengan tepat agar dana tidak tergerus terlampau besar dalam satu kali transaksi yang merugikan.

Kegiatan trading valuta asing terus meningkat dari tahun ke tahun karena peluang keuntungannya yang besar, didukung oleh sistem pasar bebas dan dilakukan oleh banyak pemain baik perorangan maupun institusi. Data hasil survei dari Bank for International Settlements dari seluruh dunia menunjukkan peningkatan perputaran (turnover) transaksi valuta asing untuk tanggal valuta spot seperti ditunjukkan pada grafik di bawah.

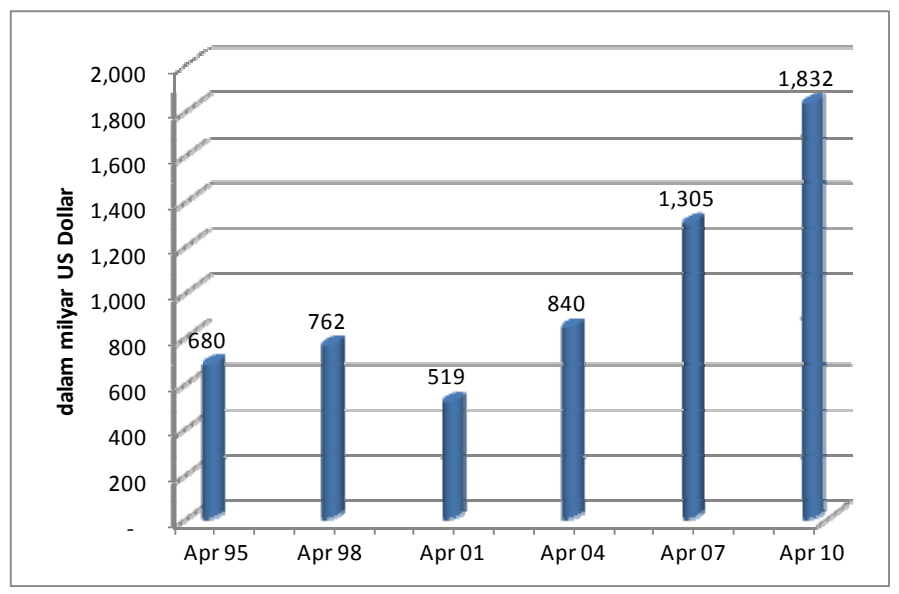

Gambar 1 Nilai Perputaran Transaksi Valuta Asing di Dunia untuk Valuta Spot (Sumber: Bank for International Settlements, diolah)

Terdapat kemungkinan bahwa transaksi spot yang terjadi di seluruh dunia tidak seluruhnya terekam dalam survei yang dilakukan oleh Bank for International Settlements tersebut karena biasanya survei dilakukan melalui perbankan. Namun hal tersebut tetap menunjukkan bahwa volume transaksi yang terjadi di pasar valuta asing sangat besar. Data tersebut juga baru untuk transaksi spot, belum mencakup transaksi terkait valuta asing lainnya seperti forward dan option.

Kegiatan trading yang sering dilakukan di pasar valuta asing memang menggunakan tanggal valuta spot, yaitu penyelesaian transaksi dilakukan pada dua hari kerja setelah transaksi. Variasi yang lain adalah tanggal valuta today (penyelesaian transaksi dilakukan pada hari terjadinya transaksi), 
tomorrow (penyelesaian transaksi dilakukan satu hari kerja setelah terjadinya transaksi) atau forward (penyelesaian transaksi dilakukan lebih dari dua hari kerja setelah terjadinya transaksi). Kurs yang ditawarkan biasanya berbeda untuk masing-masing tanggal valuta tersebut.

Walaupun investasi valuta asing sebenarnya cukup mudah dilakukan, belum banyak orang yang tahu untuk melakukan investasi tersebut, termasuk menggunakan media atau alatnya. Tulisan ini bertujuan untuk memberikan gambaran tentang valuta asing dapat diterapkan sebagai salah satu bentuk investasi. Sebagaimana halnya investasi yang lain, investasi dalam valuta asing membutuhkan media atau alat bantu untuk merealisasikannya. Sebagai alat bantu untuk investasi tersebut dapat digunakan software khusus yang biasanya disediakan oleh para broker. Dalam tulisan ini, software yang akan dibahas adalah MetaTrader 5.

\section{METODE PENELITIAN}

Metode penelitian yang dilakukan dalam tulisan ini adalah studi pustaka dan penelaahan software MetaTrader 5. Bahan-bahan penelitian diperoleh dari buku atau sumber lain seputar topik valuta asing dan online foreign exchange trading. Gambar yang ditampilkan diperoleh dari software Metatrader 5 dan sumber lain yang relevan.

Metode yang ditempuh adalah penelaahan atau tinjauan karena tujuan tulisan ini tidak untuk memperbandingkan antara software Metatrader 5 dengan software lain yang banyak terdapat di pasar. Penelaahan yang dilakukan difokuskan pada fitur-fitur penting yang sering kali dipakai dalam perdagangan valuta asing dan kegunaannya untuk menunjang investasi atau keputusan penting yang harus dilakukan para investor atau trader. Dengan demikian tulisan ini bukan merupakan petunjuk detail cara pemakaian software Metatrader 5.

Metode penelitian difokuskan pada bagaimana sebaiknya investasi valuta asing dilakukan dan penerapannya jika menggunakan software Metatrader 5. Dengan demikian peran software Metatrader 5 di sini adalah sebagai alat bantu untuk melakukan investasi valuta asing. Beberapa petunjuk penggunaan diberikan agar pembaca dapat mempraktikkan langsung langkah-langkah yang diulas dalam tulisan ini.

\section{HASIL DAN PEMBAHASAN}

Investasi valuta asing berbeda dengan investasi lainnya dalam hal jangka waktu untuk menahan investasi tersebut. Jika kita berinvestasi pada properti misalnya, kita dapat menahan investasi tersebut untuk jangka waktu 5 tahun dan berharap harga terus naik selama periode tersebut. Atau jika kita berinvestasi pada saham suatu perusahaan yang tergolong blue chip, kita dapat memegang saham tersebut selama 5 tahun dan berharap harga saham akan terus naik. Atau contoh lain lagi, jika kita memegang obligasi berjangka waktu 5 tahun dan terus memegangnya sampai jatuh tempo, setidaknya kita masih mendapatkan bunga.

Jika kita mengharapkan mendapatkan imbal hasil investasi dari valuta asing dengan cara memegangnya untuk jangka waktu lama, yang terjadi dapat saja malah sebaliknya yaitu kita tidak mendapat apa-apa (impas) atau lebih buruk lagi merugi. Potensi keuntungan tetap ada, walaupun biasanya belum tentu besar. Jika kita memegang valuta asing dalam bentuk uang fisik, maka ada potensi penurunan nilai juga karena biasanya bank atau money changer hanya menerima uang terbitan tahun-tahun terakhir. Perlu juga dicatat bahwa investasi pada valuta asing tidak mendapatkan semacam 
deviden atau bunga, kecuali kita menempatkan valuta asing tersebut dalam bentuk tabungan atau deposito, yang biasanya bunganya pun kecil. Dengan tidak adanya dividen atau bunga tersebut, berinvestasi dalam valuta asing seperti melakukan zero sum game, artinya kalau ada pihak yang menang maka ada pihak yang kalah. Dengan kata lain, jika kita untung maka pihak lain merugi, demikian pula sebaliknya.

Investasi valuta asing tidak dapat dipegang dalam jangka waktu lama karena biasanya mata uang bergerak dalam kisaran tertentu dan selama jangka waktu tertentu bisa saja bolak-balik di kisaran tersebut. Sebagai contoh dapat kita lihat pada Gambar 2. Grafik pergerakan USD/IDR periode Februari 2008 sampai dengan Februari 2013. USD/IDR memang bukan mata uang yang disarankan sebagai alat investasi karena Bank Indonesia tidak mengizinkan transaksi spekulasi terhadap USD/IDR, tetapi ini hanya sebagai ilustrasi saja supaya lebih mudah dipahami. Hal ini terkait juga dengan cukup banyak orang yang memegang tabungan USD sebagai salah satu alternatif investasi.

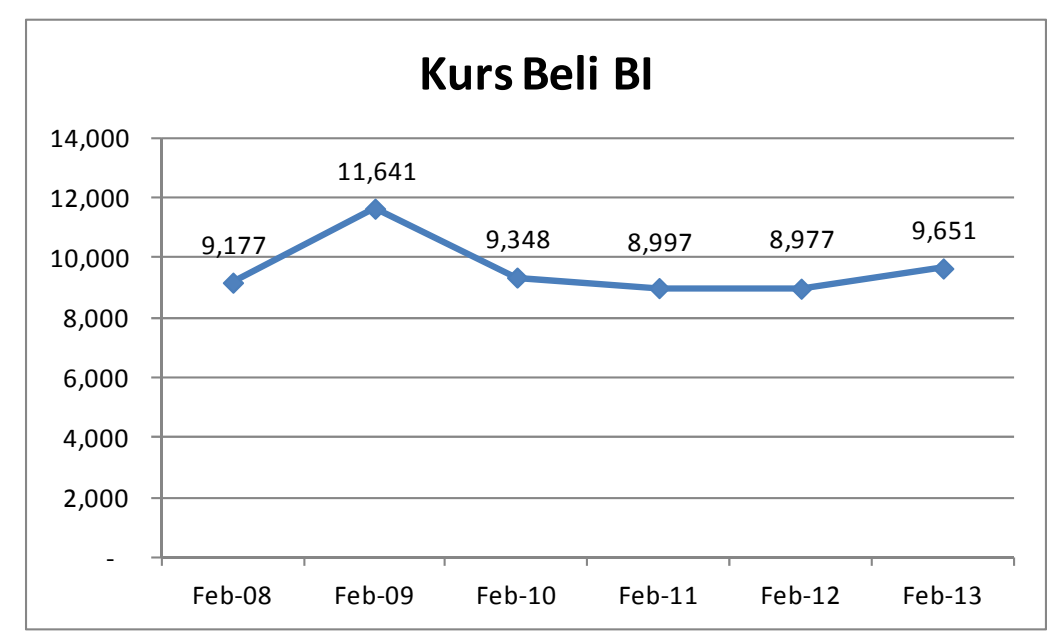

Gambar 2 Grafik Pergerakan Kurs Beli USD/IDR periode Feb 2008 - Feb 2013

(Sumber: Bank Indonesia)

Dalam grafik tersebut terlihat bahwa pada awal Februari 2008 kurs beli USD/IDR berada pada posisi USD $1=$ IDR 9.177. Lalu pada Februari 2013, kurs hanya mencapai posisi 9.651 atau hanya naik sebesar 5,17\%. Jadi mata uang memang akan selalu bergerak pada kisaran tertentu, khususnya jika situasi ekonomi dan politik di negara tersebut stabil seperti yang biasa terjadi di negara-negara maju. Pergerakan valuta asing juga biasanya terkait posisi relatif negara tersebut dibandingkan dengan negara yang lain sehingga sangat kecil kemungkinannya terdapat mata uang yang akan terus menurun dengan cepat dibandingkan mata uang negara lain, kecuali jika memang terjadi instabilitas di negara tersebut.

Hal yang perlu diketahui terkait transaksi valuta asing adalah bahwa apabila kita menjual satu mata uang, maka kita sekaligus membeli mata uang yang lain. Itu juga yang menyebabkan kurs mata uang biasanya ditulis berpasangan, misalnya USD/IDR, USD/JPY, EUR/USD. Jika disebutkan bahwa kurs EUR/USD adalah 1.3325, itu berarti jika kita ingin membeli EUR sebesar EUR 1, kita membayar dengan memberikan (atau disebut juga menjual) USD sebesar USD 1.3325. Dalam Tabel 1. Daftar Nama Pasangan Mata Uang disebutkan contoh pasangan mata uang yang sering diperdagangkan. 
Tabel 1 Daftar Nama Pasangan Mata Uang

\begin{tabular}{ll}
\hline \multicolumn{1}{c}{ Simbol } & \multicolumn{1}{c}{ Keterangan } \\
\hline USD/IDR & US Dollar/Indonesia Rupiah \\
USD/JPY & US Dollar/Japanese Yen \\
USD/CHF & US Dollar/Swiss Franc \\
USD/CAD & US Dollar/Canadian Dollar \\
EUR/USD & Euro/US Dollar \\
EUR/GBP & Euro/British Pound sterling \\
EUR/JPY & Euro/Japanes Yen \\
EUR/CHF & Euro/Swiss Franc \\
EUR/AUD & Euro/Australian Dollar \\
GBP/USD & British Pound sterling/US Dollar \\
GBP/CHF & British Pound sterling/Swiss Franc \\
GBP/JPY & British Pound sterling/Japanese Yen \\
AUD/USD & Australian Dollar/US Dollar \\
AUD/JPY & Australian Dollar/Japanese Yen \\
NZD/USD & New Zealand Dollar/US Dollar \\
\hline
\end{tabular}

Sebagai salah satu cara agar investasi pada valuta asing dapat efektif adalah dengan melakukan transaksi secara online bukan investasi konvensional-mata uang dibeli secara fisik atau dimasukkan ke tabungan. Dengan transaksi secara online, valuta asing dapat di-trading-kan secara cepat dan praktis. Apalagi pasar valuta asing dapat dikatakan buka selama 24 jam sehari selama hari kerja.

Salah satu software atau platform trading yang banyak dipakai di pasar valuta asing online adalah MetaTrader. Saat ini di pasaran terdapat dua macam versi software MetaTrader yaitu MetaTrader 4 dan MetaTrader 5. Software MetaTrader versi 4 saat ini lebih banyak digunakan oleh para broker penyedia jasa transaksi valuta asing online.

Menurut Wira (2013:38), MetaTrader mempunyai keunggulan dibanding platform trading yang lain, yaitu: ringan dan cepat, bisa berjalan dengan baik walau koneksi internet tidak terlalu cepat; memiliki tampilan yang user friendly, mudah digunakan; memiliki indikator standar yang cukup banyak; memiliki MQL (MetaQuotes Language), yaitu bahasa pemrograman untuk membuat indikator sendiri; dan memiliki fitur Expert Advisor, yang memungkinkan trading secara otomatis, tidak lagi manual.

Sedangkan perbedaan antara MetaTrader 4 dan MetaTrader 5 (Wira, 2013:38) secara umum sebagai berikut. Pertama, MetaTrader 5 lebih cepat dari pendahulunya. Kedua, MetaTrader 5 dapat digunakan untuk trading saham. Ketiga, MetaTrader 5 lebih user friendly dengan ikon yang lebih besar. Keempat, Program MQL di MetaTrader 5 lebih canggih dan cepat, parameternya mirip dengan $\mathrm{C}++$. Kelima, sistem order di MetaTrader 5 berbeda jauh dengan MetaTrader 4. Secara singkat, sistem order di MetaTrader 5 mengaplikasikan sistem netting order sedangkan di MetaTrader 4 tidak dilakukan netting untuk order. Sebagai contoh, jika kita melakukan order beli 2 unit dan order jual 1 unit, pada MetaTrader 5 order kita akan menjadi order beli sebanyak 1 unit. Sedangkan di MetaTrader 4 akan tetap tercatat dua macam order tersebut.

Untuk mendapatkan MetaTrader 5 kita dapat mengunduh installer-nya secara gratis dari internet ataupun dapat kita peroleh dari broker apabila kita membuka account di broker tertentu. Tampilan jendela/layar awal dari MetaTrader 5 sebagaimana pada gambar 3. Pada gambar tersebut terlihat bahwa tampilan jendela awal terbagi menjadi beberapa bagian, yaitu: menu pada bagian atas; jendela "Market Watch" di sebelah kiri atas yang menunjukkan berbagai simbol pasangan mata uang dan posisi kurs terkini; jendela "Navigator" di bagian bawah kurs yang berisi antara lain indikatorindikator yang dapat digunakan dalam analisis teknikal; bagian tengah yang merupakan layar utama 
terbagi menjadi empat bagian yang di dalamnya berisi grafik dari pasangan mata uang tertentu; bagian bawah yang disebut "Toolbox" berisi berbagai macam keterangan.

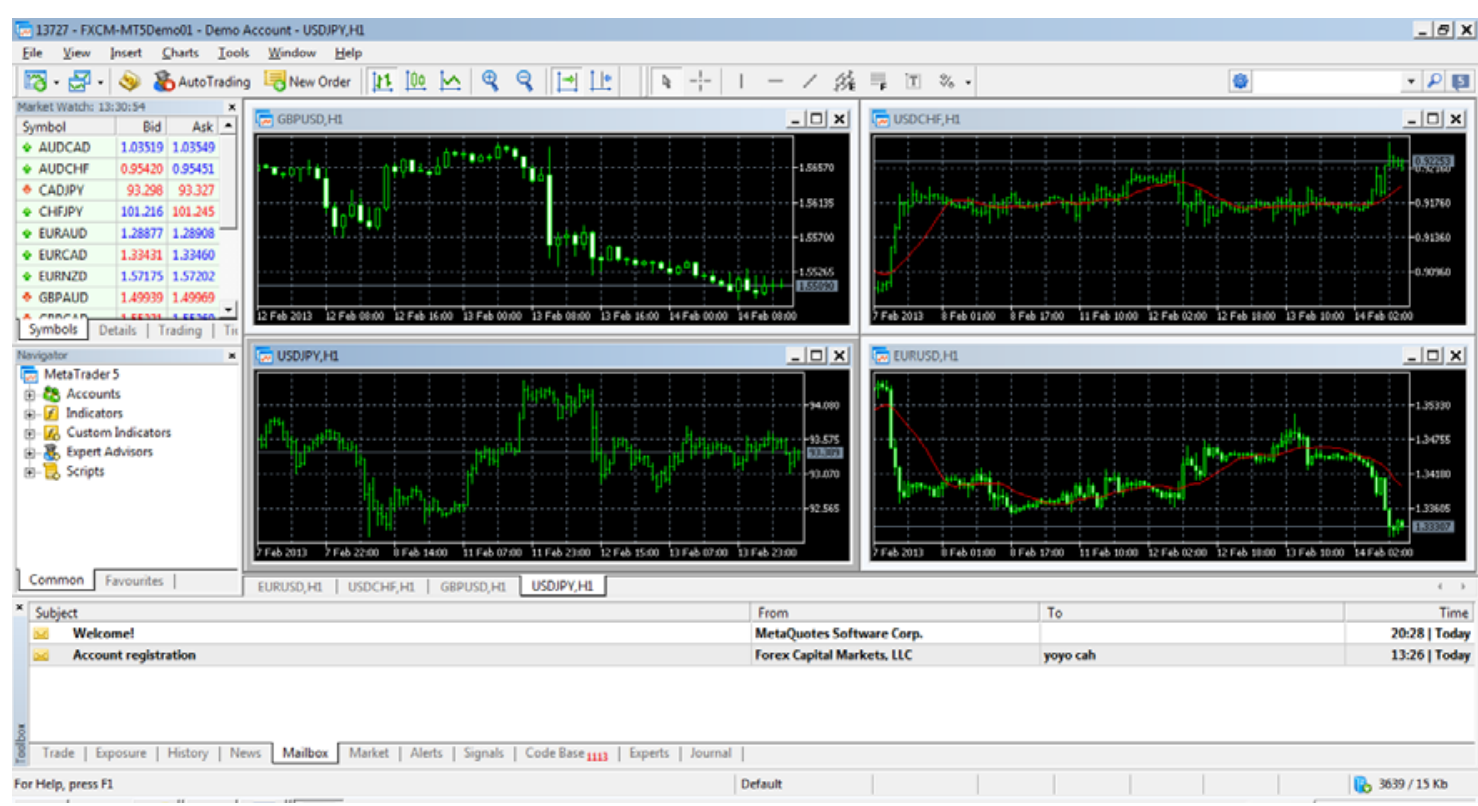

Gambar 3 Tampilan Awal MetaTrader 5

Tampilan MetaTrader 5 tersebut memang lebih banyak berhubungan dengan analisis yang dapat dilakukan, khususnya secara teknikal karena yang ditampilkan adalah grafik harga. Terdapat tiga macam grafik harga yang dapat ditampilkan di MetaTrader 5 yaitu grafik batang atau bar chart (gambar 4), grafik lilin atau candlestick chart (gambar 5), dan grafik garis atau line chart (gambar 6). Grafik candlestick biasanya lebih mudah dipakai dibandingkan grafik yang lain karena kemampuan candlestick untuk memberikan pandangan sekilas atas situasi bullish (harga naik) atau bearish (harga turun). Hal tersebut dimungkinkan karena candlestick menggunakan warna yang berbeda untuk komponen penyusun grafik yang sifatnya bullish dan bearish.

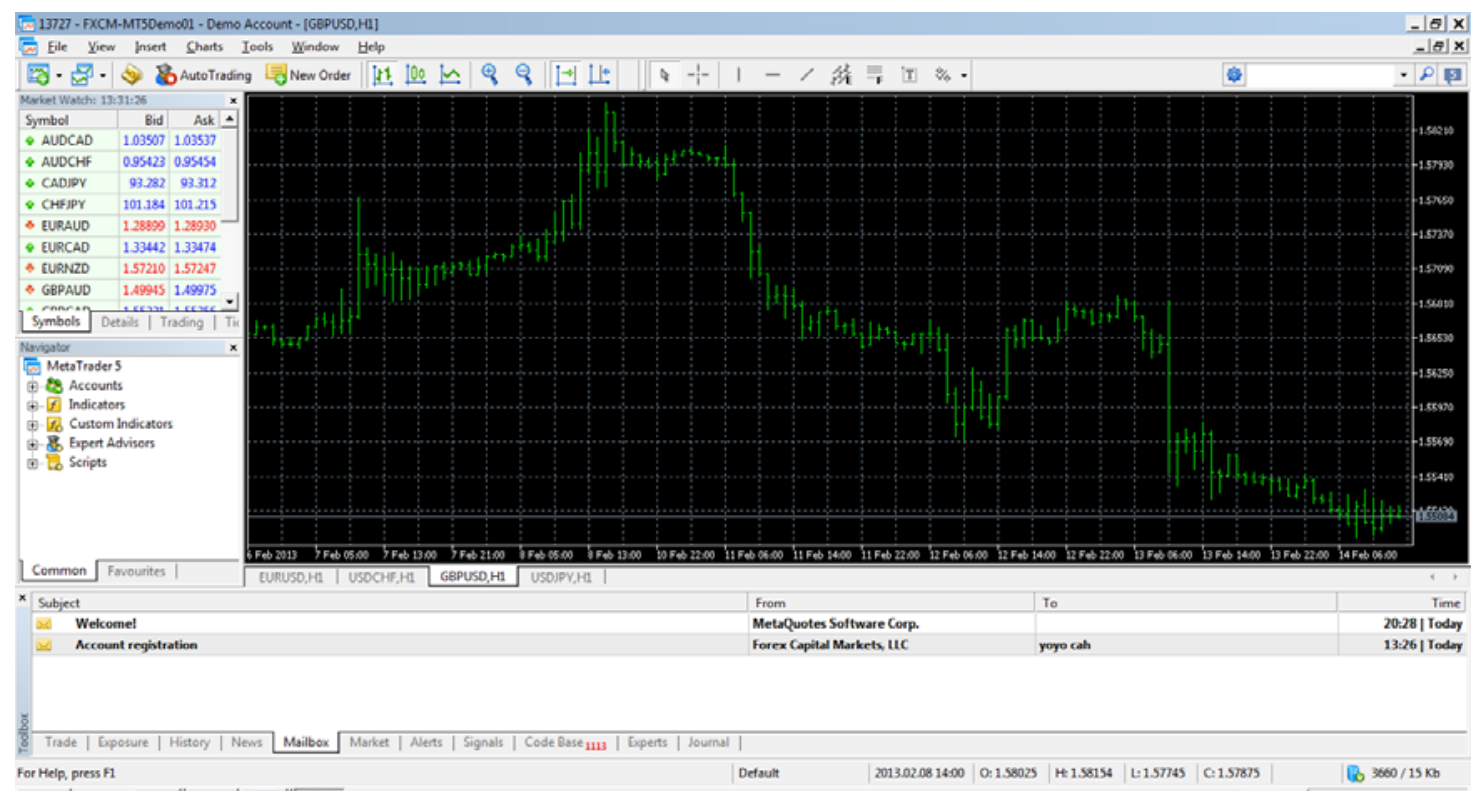

Gambar 4 Bar Chart pada MetaTrader 5 


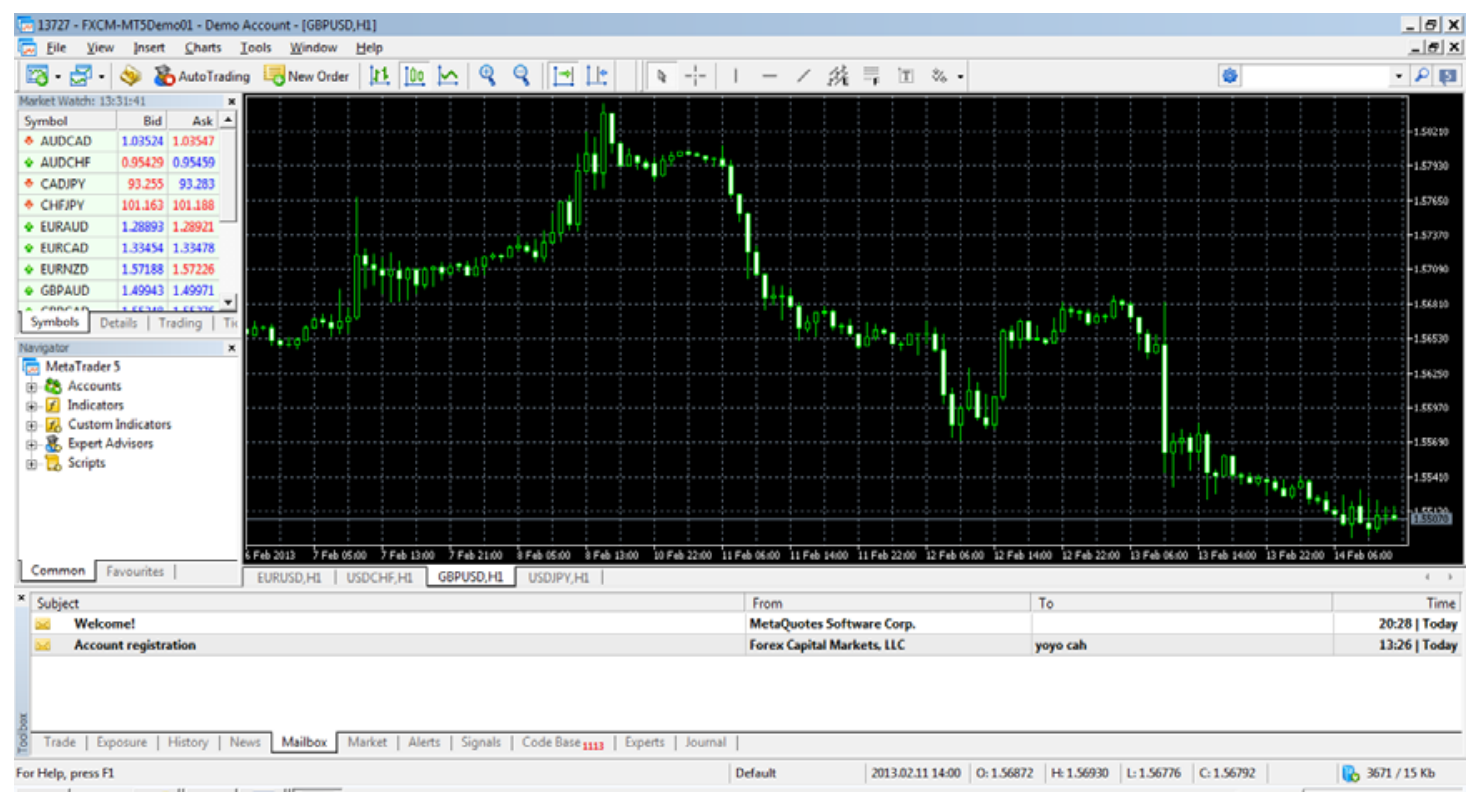

Gambar 5 Candlestick Chart pada MetaTrader 5

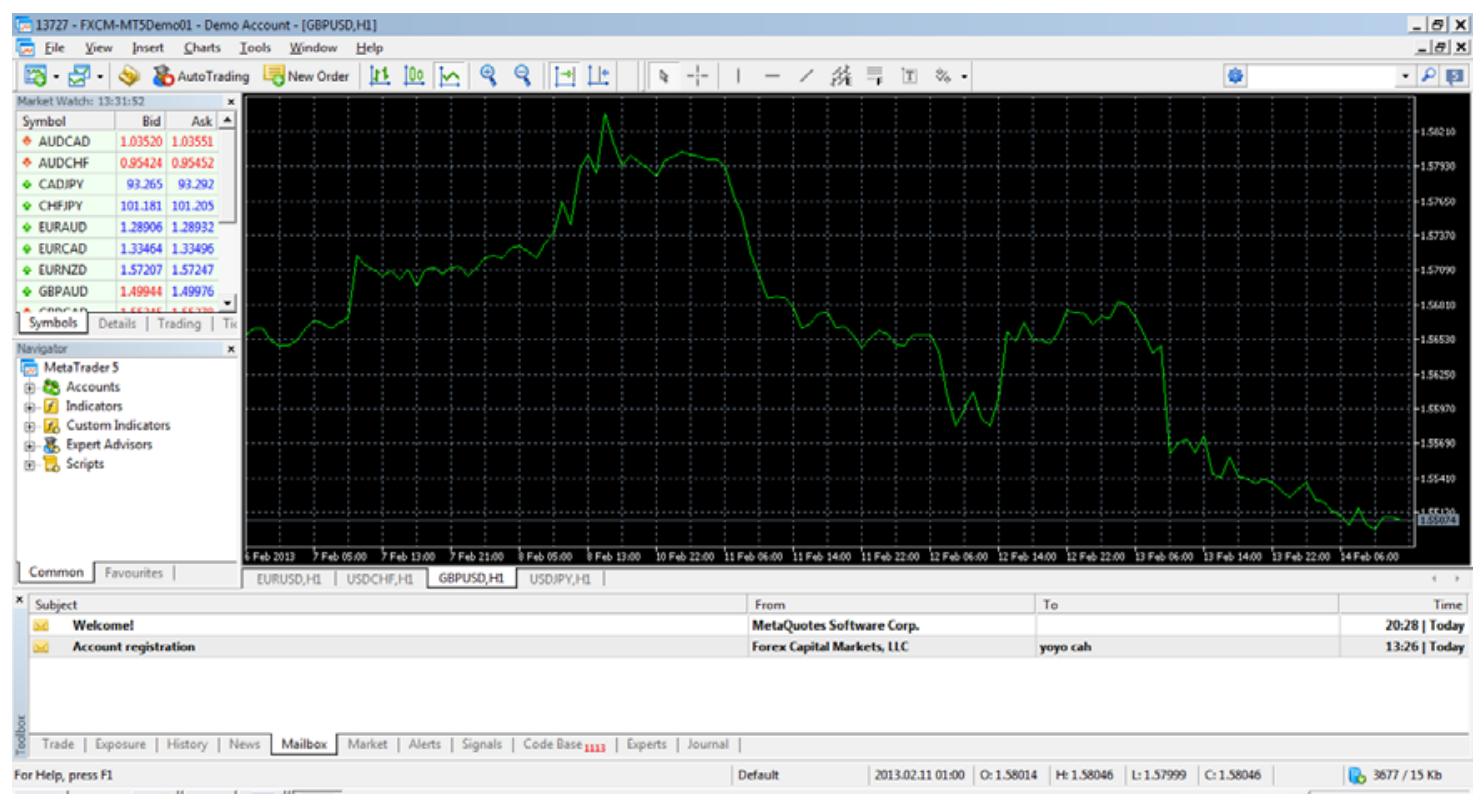

Gambar 6 Line Chart pada MetaTrader 5

Biasanya grafik candlestick menggunakan warna putih untuk bullish dan warna hitam untuk bearish seperti terlihat pada gambar 7. Namun pada MetaTrader 5, warna grafik candlestick bullish dan bearish standar dibedakan menjadi tidak berwarna (kosong) untuk bullish dan putih untuk bearish. Tampilan tersebut dapat diganti pada setting warna tampilan dengan cara menekan tombol F8 atau menekan klik kanan pada mouse dan memilih properties.Setting warna dapat diganti pada tab colors. Memang tampilan candlestick bisa berbeda-beda pada berbagai software tetapi warna untuk bullish dan bearish pasti konsisten. 


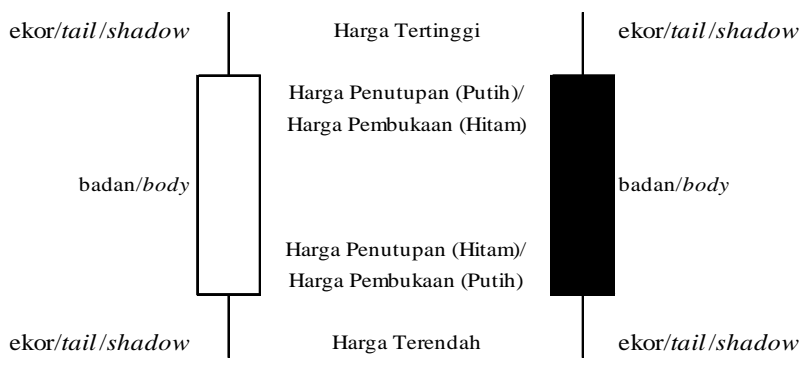

Gambar 7 Contoh Candlestick

Gambar 8 di bawah menunjukkan cara order dilakukan menggunakan MetaTrader 5. Karena sifat pergerakan valuta asing yang sering kali sangat cepat, maka terdapat gambar pergerakan per tick pada layar kecil sebelah kiri. Garis sebelah atas adalah harga bid sedangkan garis sebelah bawah adalah harga offer. Kita juga dapat memilih apakah akan melakukan Instant Execution atau Pending Order.

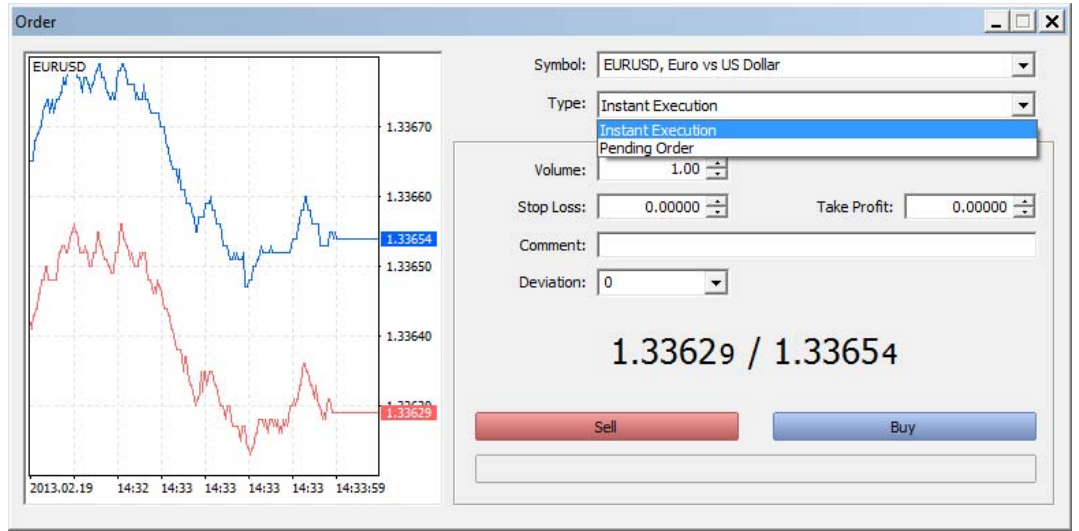

Gambar 8 Layar Order

Hal ini memberikan keleluasaan apabila berdasarkan analisis, kita misalnya ingin membeli EUR/USD tetapi bukan pada level sekarang, kita dapat memilih Pending Order. Jika kita memilih melakukan Pending Order, tampilan akan berubah seperti gambar 9. Kita dapat memilih ingin membeli atau menjual di harga tertentu. Ada beragam variasi pilihan menu yang dapat dipilih, bergantung kepada kebutuhan kita.

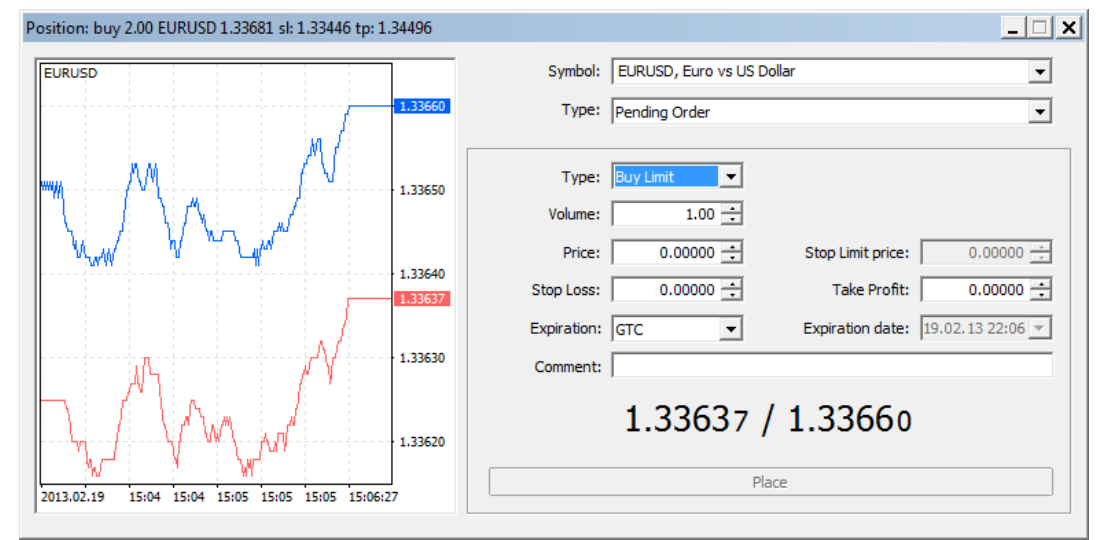

Gambar 9 Pending Order 
Jika kita memilih Instant Execution, dengan mengklik tombol Sell atau Buy, kita dapat langsung secara cepat melakukan transaksi. Jika ternyata harga berubah secara cepat, akan muncul pesan seperti pada gambar 10. Pesan tersebut menawarkan jika kita menerima penawaran harga yang baru. Artinya, jika kita menekan tombol Accept, kurs yang kita terima berbeda dengan saat kita menekan tombol beli atau jual sebelumnya.

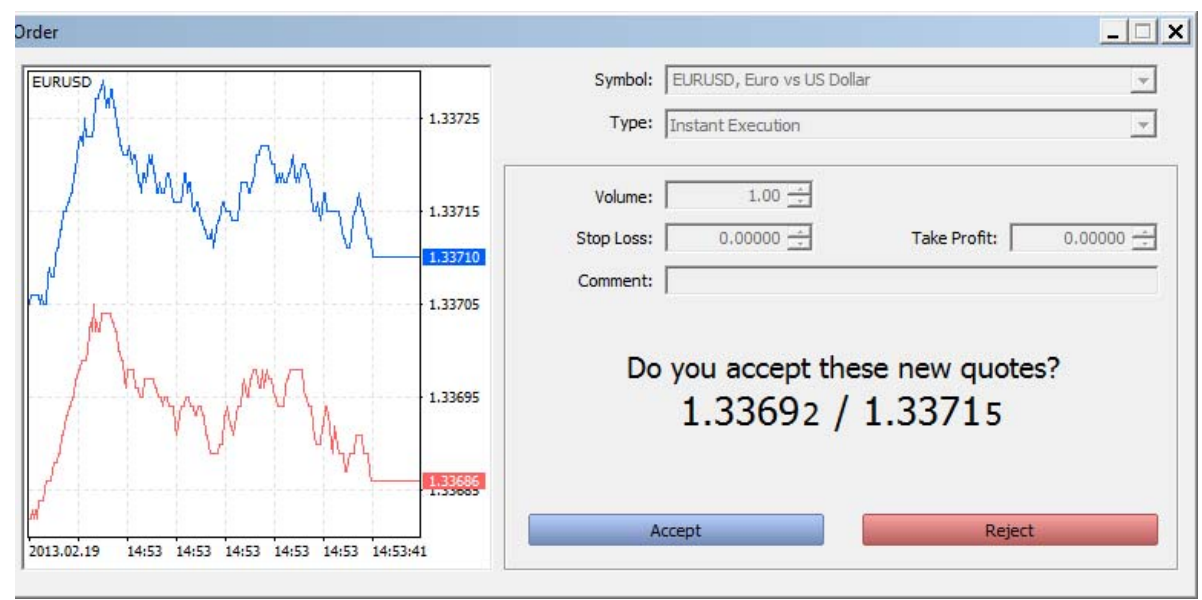

Gambar 10 New Quotes

Selanjutnya, jika kita misalnya kita sudah membeli EUR/USD, kita dapat melakukan modifikasi order untuk memasang level kurs untuk Stop Loss dan Take Profit, seperti terlihat pada gambar 11. Hal ini penting karena jika kita melakukan trading seperti ini, seharusnya sebelum mengambil posisi (beli atau jual), kita telah melakukan perencanaan terlebih dahulu berdasarkan analisis kita. Perencanaan tersebut berupa level kerugian yang bersedia kita tanggung dan level keuntungan yang menjadi target kita. Ini biasanya disebut sebagai trading plan.

Trading plan perlu dilakukan sebelum mengambil posisi untuk meminimalkan efek emosi ketika sudah mengambil posisi yang dapat membuat keputusan menjadi bias. Kedisiplinan pada trading plan tersebut dapat memengaruhi tingkat kesuksesan trading. Pengendalian emosi adalah salah satu kunci sukses dalam trading seperti ini. Apalagi dengan tingkat kecepatan pergerakan valuta asing yang sering cukup tinggi, dapat memberikan tingkat stress yang tinggi pula bagi para trader.

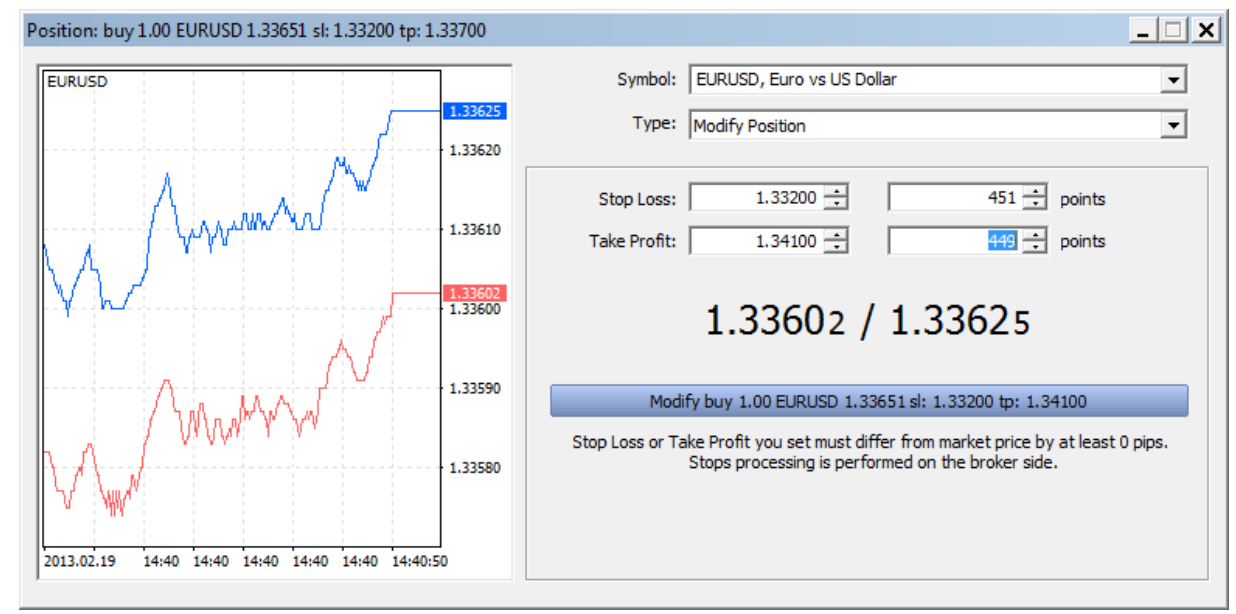

Gambar 11 Modifikasi Order 
Posisi yang kita miliki dapat terpantau seperti terlihat pada gambar 12. Selain keterangan di bagian bawah yang memuat pergerakan keuntungan dan kerugian, terdapat pula garis yang menandai posisi beli kita dan order Stop Loss dan Take Profit yang telah kita pasang. Hal ini penting karena sewaktu-waktu kita perlu mengetahui kondisi portofolio kita. Kadang kala dapat terjadi situasi yang benar-benar berubah arah, misalnya karena peristiwa tertentu yang membuat kita harus langsung mengambil tindakan dengan menutup posisi kita walaupun order yang kita pasang belum tersentuh.

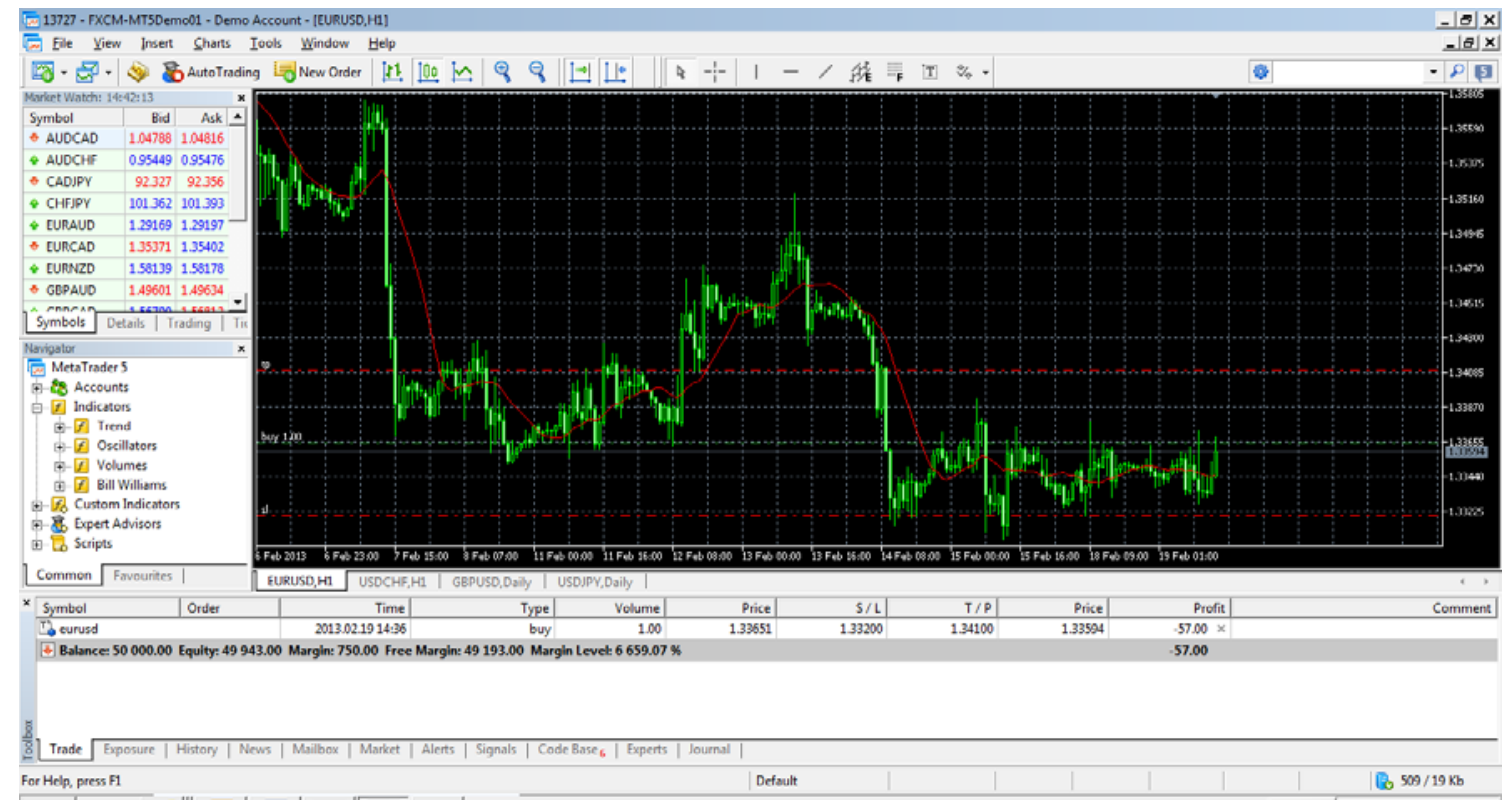

Gambar 12 Informasi Posisi

\section{SIMPULAN}

Berdasarkan pembahasan yang telah diuraikan terlihat bahwa valuta asing dapat menjadi salah satu alternatif investasi. Meskipun demikian, investasi pada valuta asing bukanlah sesuatu yang mudah walaupun dapat dipelajari. Karena sifatnya yang bergerak cepat, investasi pada valuta asing tidak cocok jika dipegang terus-menerus dalam jangka waktu lama. Lebih baik jika dilakukan trading terhadap valuta asing tersebut.

Software MetaTrader 5 dapat membantu dalam melakukan transaksi valuta asing secara online sehingga menjadi lebih mudah, cepat, dan ringkas. Fitur-fitur dasarnya dapat dikatakan cukup lengkap dan mendukung untuk mengimbangi pergerakan valuta asing yang sering kali sangat cepat.

Yang perlu dilakukan calon investor adalah mempelajari terlebih dahulu cara pakai software tersebut. Hal ini terutama supaya tidak terjadi kepanikan pada saat telah melakukan transaksi dan ternyata harus segera menutup kerugian atau misalnya salah mengeksekusi transaksi. Software tersebut menyediakan account demo yang dapat dipakai untuk uji coba. Uji coba ini perlu dilakukan supaya calon investor/trader dapat mempelajari dan mengenali bagaimana situasi pasar valuta asing.

Penelaahan lebih lanjut terhadap penggunaan software MetaTrader 5 dapat dilakukan agar fungsi-fungsi detailnya dapat diketahui. Juga dapat ditelaah kelebihan dan kekurangan software tersebut dalam memfasilitasi transaksi valuta asing. Penelitian lebih lanjut terhadap investasi dalam valuta asing juga dapat dikembangkan mengingat dinamika perkembangan valuta asing yang sangat cepat dan dipengaruhi oleh banyak hal. 


\section{DAFTAR PUSTAKA}

Ardiayan, A. (2012). The Master Traders: Belajar dari Traders Sukses Dunia. Jakarta: Gramedia Pustaka Utama.

Jones, C. P. (2010). Investment: Analysis and Management. New Jersey: John Wiley \& Sons.

Pojarliev, M., Levich, R. M. (2008). Do Professional Currency Managers Beat The Benchmark? Financial Analysts Journal. 62 (5): 18 - 32.

Widoatmodjo, S., Ferlianto, L. R., Rizal, J., Batubara, J. (2012). Forex Online Trading: Tren Investasi Masa Kini. Jakarta: Elex Media Komputindo.

Wira, D. (2013). Jurus CUAN Online Forex Trading. Jakarta: Exceed. 